P-ISSN: 2085-2541, E-ISSN: 2715-7865

Volume 12, Nomor 2, Desember 2020

https://ejournal.staindirundeng.ac.id/index.php/Tasyri

\title{
PERKEMBANGAN EKONOMI MAKRO PROVINSI ACEH MASA PANDEMI COVID-19
}

\author{
Mikhral Rinaldi \\ Dosen Perbankan Syariah STAIN Tgk Dirundeng Meulaboh \\ mikhralrinaldi@staindirundeng.ac.id
}

\begin{abstract}
Abstrak
Penelitian ini bertujuan untuk melihat perkembangan ekonomi makro di provinsi aceh selama terjadinya pandemi COVID-19, penelitian ini menggunakan data sekunder dan kemudian dikaji secara kepustakaan dari berbagai sumber seperi Bank Indonesia dan Badan Pusat Statistik yang secara khusus mengkaji ekonomi regional suatu daerah. Metode penelitian yang digunakan bersifat kualitatif deskriptif yang menggunakan analisis terhadap data ekonomi makro provinsi aceh triwulan I dan triwulan II tahun 2020. Dalam penelitian ini, kajian ekonomi makro provinsi aceh dilihat dari dua, yaitu sisi pengeluaran dan sisi lapangan usaha. Hasil analisis menunjukkan bahwa kinerja ekonomi makro provinsi aceh selama pandemi COVID-19 mengalami kontraksi baik dari sisi pengeluaran maupun sisi lapangan usaha. Ditinjau dari sisi pengularan, penyebab utama kontraksi yang terjadi dikarenakan defisit neraca ekspor antar daerah dan negatifnya ekspor luar negeri. Sementara itu dari sisi lapangan usaha, kontraksi ekonomi utama di sebabkan oleh menurunnya lapangan usaha perdagangan besar dan eceran dan lapangan usaha transportasi. Lapangan usaha pertanian, perikanan dan kehutanan juga mengalami kontraksi akibat berkurangnya aktivitas masyarakat selama pandemi COVID-19 dan terjadinya penurunan daya beli masyarakat.
\end{abstract}

Kata Kunci: Makro ekonomi, COVID-19.

\begin{abstract}
This study aims to look at macroeconomic developments in the province of Aceh during the COVID-19 pandemic, this study uses secondary data and then reviewed in literature from various sources such as Bank Indonesia and the Central Bureau of Statistics which specifically study the regional economy of a region. The research method used is descriptive qualitative in nature which uses analysis of the macroeconomic data of Aceh province in the first quarter and second quarter of 2020. In this study, the macroeconomic study of Aceh province is seen from two, namely the expenditure side and the business field side. The results of the analysis show that the macroeconomic performance of Aceh province during the COVID-19 pandemic has contracted both in terms of expenditure and the side of business fields. In terms of contagion, the main cause of the contraction was the deficit in the inter regional export balance and negative exports from abroad. Meanwhile, from the business sector side, the main economic contraction was caused by a decline in the wholesale and retail trade and transportation business fields. Agricultural, fishery and forestry business fields have also contracted due to reduced community activities during the COVID-19 pandemic and a decline in people's purchasing power.
\end{abstract}

Keywords: Macro economy, COVID-19. 


\section{A. PENDAHULUAN}

Kasus pandemi COVID-19 mulai terjadi di indonesia pada tanggal 3 Maret 2020 hingga sekarang dengan total 361.067 kasus, 285.325 dinyatakan sembuh dan sebanyak 12.511 orang meninggal sedangkan untuk provinsi aceh tercatat 6.551 kasus, dengan kesembuhan sebesar 4.605 orang dan meninggal dunia sebanyak 233 orang 1 . Pandemi COVID-19 menekan pertumbuhan ekonomi Indonesia triwulan II 2020, sehingga mengalami kontraksi 5,32\% (yoy), turun signifikan dibandingkan dengan capaian triwulan I 2020 yang tumbuh sebesar $2,97 \%$ (yoy). Perkembangan ini tidak terlepas dari pengaruh melemahnya ekonomi global sejalan dengan pandemi COVID-19 dan menurunnya aktivitas ekonomi domestik sebagai dampak kebijakan Pembatasan Sosial Berskala Besar untuk mencegah penyebaran pandemi COVID-19.

Penurunan pertumbuhan ekonomi domestik tersebut terjadi di seluruh komponen PDB. Sejalan dengan terjadinya kontraksi ekonomi Nasional, pada triwulan II 2020 ekonomi Sumatera juga tercatat terkontraksi $-3,01 \%$ (yoy), turun dalam dibandingkan periode sebelumnya yang tumbuh 3,25\% (yoy). Kontraksi tersebut sejalan dengan pembatasan aktivitas masyarakat sebagai dampak mitigasi pandemi, sehingga menekan kinerja konsumsi rumah tangga dan investasi. Sementara itu dari sisi Lapangan Usaha (LU), seluruh LU utama Sumatera seperti pertanian, industri pengolahan, perdagangan, dan pertambangan mengalami deselerasi kinerja sehubungan dengan kondisi permintaan yang rendah. Secara spasial, kontraksi ekonomi terdalam provinsi di Sumatera terjadi di Kepulauan Riau -6,90\%, Bangka Belitung -4,98\%, serta Sumatera Barat $-4,91 \%$.

\footnotetext{
${ }^{1}$ Indonesia.covid19.go.id (per 19 Okt 2020)
}

Grafik 1.1 Pertumbuhan Ekonomi Prov. di Sumatera per triwulan II 2020

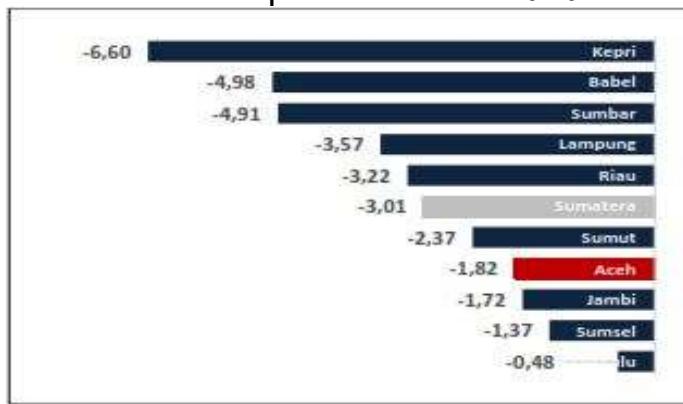

Sumber : BPS, diolah

Grafik 1.2 Pertumbuhan ekonomi

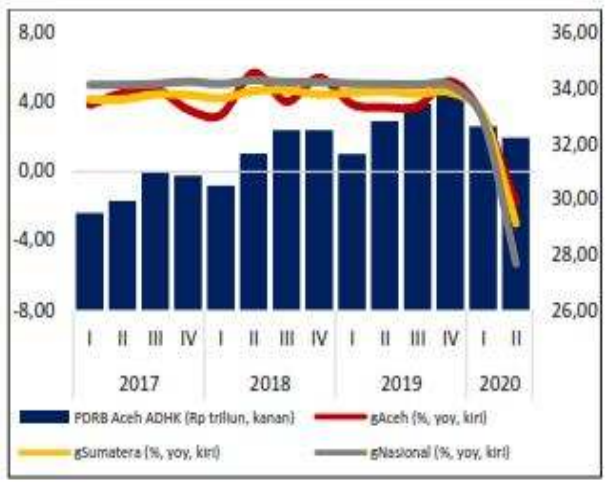

Sumber : BPS, diolah

Jika dilihat secara andil kapasitas perekonomian dari PDRB ADHK, Aceh tercatat memiliki pangsa sebesar 5,74\% terhadap perekonomian sumatera. Sumbangan tersebut tidak mengalami banyak perubahan dibandingkan periode-periode sebelumnya. Dengan proporsi tersebut Aceh masih menjadi provinsi dengan perekonomian ketiga terkecil di sumatera setelah bengkulu $(2,04 \%)$ dan kepulauan bangka belitung (2,29\%). Sementara itu sumut, riau, dan sumsel masih menjadi provinsi dengan sumbangsih ekonomi paling dominan di sumatera dengan menyumbang $60 \%$ dari total ekonomi sumatera.

Dengan terjadinya kontraksi ekonomi nasional dan ekonomi sumatera pada triwulan II, perekonomian aceh juga mengalami kontraksi sebesar $1,82 \%$, turun signifikan dibandingkan dengan triwulan I yang tumbuh sebesar 3,17\%. Ditinjau dari sisi pengeluaran, kontraksi ekonomi aceh disebabkan oleh defisit ekspor antar daerah 
dan kontraksi ekspor luar negeri. Sementara itu dari sisi lapangan usaha, bidang transportasi, pergudangan dan perdagangan besar dan eceran menjadi penyebab utama kontraksi ekonomi.

\section{B. KAJIAN PUSTAKA}

\section{Konsumsi rumah tangga}

Teori konsumsi Keynes mengedepankan tentang analisis perhitungan statistik, serta membuat hipotesis berdasarkan observasi kasual. Keynes menganggap perhitungan fluktuasi ekonomi negara dapat dihitung berdasarkan besarnya konsumsi dan pendapatan belanja rumah tangga. Pada pengeluaran rumah tangga, selalu terdapat pengeluaran untuk konsumsi walaupun tidak memiliki pendapatan. Hal ini disebut sebagai pengeluaran konsumsi autonomus atau autonomus consumption. Keynes memiliki teori konsumsi absolut yang disebut sebagai Teori Konsumsi Keynes (absolute income hypothesis). Keynes berpendapat bahwa besarnya konsumsi rumah tangga, tergantung dari pendapatan yang dihasilkan. Perbandingan antara besarnya konsumsi dan pendapatan disebut Keynes sebagai Marginal Propensity to Consume (MPC). MPC ini digunakan untuk mengukur bahwa semakin besar pendapatan yang dimiliki, maka tingkat konsumsi rumah tangga juga tinggi, dan begitu pula sebaliknya ${ }^{2}$.

\section{Konsumsi/pengeluaran pemerintah}

Untuk memacu pertumbuhan ekonomi, perlu dilakukan kebijakan fiskal baik melalui penerimaan pemerintah yang berupa pajak maupun melalui pengeluaran pemerintah (government expenditure). Dampak kebijakan tersebut terhadap pertumbuhan ekonomi salah satunya ditandai dengan angka pengganda pengeluaran, yaitu angka yang menunjukkan besarnya kelipatan penambahan output nasional jika terjadi penambahan pengeluaran investasi atau pengeluaran pemerintah. Angka pengganda

${ }^{2}$ Sadono Sukirno, Pengantar Teori Ekonomi Makro, (Jakarta: Prenada Media Group, 2005) itulah yang memberi sinyal adanya dampak kebijakan fiskal (pengeluaran pemerintah) terhadap pertumbuhan ekonomi ${ }^{3}$.

\section{Investasi/Pembentukan Modal Tetap Bruto (PMTB)}

Investasi adalah penanaman modal untuk biasanya berjangka panjang dengan harapan mendapatkan keuntungan di masa yang akan datang sebagai kompensasi secara profesional atas penundaan konsumsi, dampak inflasi dan resiko yang ditanggung. Keputusan investasi dapat dilakukan individu, dari investasi tersebut yang dapat berupa capital gain/loss dan yield. Alasan seorang investor melakukan investasi adalah untuk mendapatkan kehidupan yang lebih baik di masa yang akan datang serta untuk menghindari merosotnya nilai kekayaan yang dimiliki. Saham merupakan salah satu alternatif dalam aset finansial. Kebutuhan akan informasi yang relevan dalam pengambilan keputusan investasi dalam aset finansial di pasar modal sangat dibutuhkan oleh investor. Suatu pendekatan dalam menganalisis harga saham dipasar modall sangat dibutuhkan oleh investor. Suatu pendekatan dalam menganalisis harga saham dipasar modal yang dapat membantu investor dalam membuat keputusan investasi adalah pendekatan fundamental dan teknikal ${ }^{4}$. Pendekatan secara fundamental mendasarkan analisanya pada suatu anggapan bahwa setiap saham mempunyai nilai intrinsik dihasilkan. Salah satu indikator yang dapat digunakan yaitu apabila semakin rendah harga suatu saham maka semakin bagus untuk melakukan investasi, hal tersebut dikarenakan harga saham dapat terjangkau oleh kemampuan investor dan memiliki nilai resiko yang kecil.

\section{Ekspor Luar Negeri}

Ekspor adalah penjualan barang ke luar negeri dengan menggunakan sistem pembayaran, kualitas, kuantitas dan syarat penjualan lainnya yang telah disetujui oleh

\footnotetext{
${ }^{3}$ Mankiw, N, Gregory, Macroeconomic, 2010, 7th edition, worth Publisher

4 Todaro, Smith. Economic Development, Pearson Education Limited, United Kingdom (2006)
} 
pihak eksportir dan importir. Proses ekspor pada umumnya adalah tindakan untuk mengeluarkan barang atau komoditas dari dalam negeri untuk masuk ke negara lain. Ekspor barang secara besar umumnya membutuhkan campur tangan dari bea cukai di negara pengirim maupun penerima. Ekspor adalah bagian penting dari perdagangan internasional. Penjualan barang oleh eksportir keluar negeri dikenai berbagai ketentuan dan pembatasan serta syarat-syarat khusus pada jenis komoditas tertentu termasuk cara penanganan dan pengamanannya. Setiap negara memiliki peraturan dan ketentuan perdagangan yang berbeda-beda. Khusus ekspor komoditas pertanian dan perikanan di Indonesia sebagian besar tidak memiliki ketentuan dan syarat yang terlalu rumit bahkan pemerintah saat ini mempermudah setiap perusahaan untuk mengekspor hasil pertanian dan perikanannya ke luar negeri.

\section{Impor Luar Negeri}

Impor adalah proses pembelian barang atau jasa asing dari suatu negara ke negara lain. Impor barang secara besar umumnya membutuhkan campur tangan dari bea cukai di negara pengirim maupun penerima. Impor adalah bagian penting dari perdagangan internasional. Jika perusahaan menjual produknya secara lokal, mereka dapat manfaat karena harga lebih murah dan kualitas lebih tinggi dibandingkan pasokan dari dalam negeri. Impor juga sangat dipengaruhi 2 faktor yakni, pajak dan kuota. Tingkat impor dipengaruhi oleh hambatan peraturan perdagangan. Pemerintah mengenakan tarif (pajak) pada produk impor. Pajak itu biasanya dibayar langsung oleh importir, yang kemudian akan membebankan kepada konsumen berupa harga lebih tinggi dari produknya. Demikianlah sebuah produk mungkin berharga terlalu tinggi dibandingkan produk yang berasal dari dalam negeri. Ketika pemerintah asing menerapkan tarif, kemampuan perusahaan asing untuk bersaing di Negara-negara itu dibatasi. Pemerintah juga dapat menerapkan kuota pada produk impor, yang membatasi jumlah produk yang dapat diimpor. Jenis hambatan perdagangan seperti ini bahkan lebih membatasi dibandingkan tarif, karena secara eksplisit menetapkan batas jumlah yang dapat diimpor.

\section{Lapangan Usaha Pertanian, Perikanan, dan Kehutanan}

Pertanian adalah kegiatan pemanfaatan sumber daya hayati yang dilakukan manusia untuk menghasilkan bahan pangan, bahan baku industri, atau sumber energi, serta untuk mengelola lingkungan hidupnya. Kegiatan pemanfaatan sumber daya hayati yang termasuk dalam pertanian, biasa dipahami orang sebagai budidaya tanaman atau bercocok tanam (bahasa Inggris: crop cultivation) serta pembesaran hewan ternak (raising), meskipun cakupannya dapat pula berupa pemanfaatan mikroorganisme dan bio enzim dalam pengolahan produk lanjutan, seperti pembuatan keju dan tempe, atau sekedar ekstraksi semata, seperti penangkapan ikan atau eksploitasi hutan.

Perikanan adalah kegiatan manusia yang berhubungan dengan pengelolaan dan pemanfaatan sumberdaya hayati perairan. Sumberdaya hayati perairan tidak dibatasi secara tegas dan pada umumnya mencakup ikan, amfibi, dan berbagai avertebrata penghuni perairan dan wilayah yang berdekatan, serta lingkungannya. Kehutanan adalah suatu praktek untuk membuat, mengelola, menggunakan melestarikan hutan untuk kepentingan manusia. Kehutanan merupakan segala bidang yang berhubungan dengan alam seperti hutan dan makhluk hidup didalamnya

\section{Lapangan Usaha Perdagangan}

Perdagangan adalah kegiatan membeli barang dari suatu tempat (tempat yang menghasilkan barang/produsen) dan menjualnya ke tempat lain (ke konsumen) dengan tidak mengubah sifat barang, dengan tujuan memperoleh keuntungan.

Yang melakukan perdagangan tersebut (pedagang) ialah siapa saja yang menjalankan kegiatan membeli barang dan menjualnya kembali tanpa mengubah sifat 
barang yang diperjualbelikan itu dengan tujuan memperoleh keuntungan (laba). Pedagang tidak mengubah sifat barang yang diperdagangkan, sebab apabila mengubah sifat barang berarti bukan perdagangan lagi tetapi termasuk lapangan industri dan tergolong usaha produksi. Keuntungan pedagang diperoleh dari selisih lebih antara harga jual dengan harga belinya. Perdagangan merupakan penghubung antara produsen dengan konsumen.

\section{Lapangan Usaha Konstruksi}

Konstruksi merupakan suatu kegiatan membangun sarana maupun prasarana. Dalam sebuah bidang arsitektur atau teknik sipil, sebuah konstruksi juga dikenal sebagai bangunan atau satuan infrastruktur pada sebuah area atau pada beberapa area. Secara ringkas konstruksi didefinisikan sebagai objek keseluruhan bangunan yang terdiri dari bagian-bagian struktur. Misal, Konstruksi Struktur Bangunan adalah bentuk/bangun secara keseluruhan dari struktur bangunan. Contoh lain: Konstruksi Jalan Raya, Konstruksi Jembatan, Konstruksi Kapal, dan lain lain. Konstruksi dapat juga didefinisikan sebagai susunan (model, tata letak) suatu bangunan (jembatan, rumah, dan lain sebagainya) Walaupun kegiatan konstruksi dikenal sebagai satu pekerjaan, tetapi dalam kenyataannya konstruksi merupakan satuan kegiatan yang terdiri dari beberapa pekerjaan lain yang berbeda.

\section{Lapangan Usaha Pertambangan}

Pertambangan adalah sebagian atau seluruh tahapan kegiatan dalam rangka penelitian, pengelolaan dan pengusahaan mineral atau batu bara yang meliputi penyelidikan umum, eksplorasi, studi kelayakan, konstruksi, penambangan, pengolahan dan pemurnian, pengangkutan dan penjualan, serta kegiatan pasca tambang. Pertambangan adalah salah satu jenis kegiatan yang melakukan ekstraksi mineral dan bahan tambang lainnya dari dalam bumi. Penambangan adalah proses pengambilan material yang dapat diekstraksi dari dalam bumi. Tambang adalah tempat terjadinya kegiatan penambangan.

\section{Penelitian Terdahulu}

a. Hanoatubun. (2020). Dampak Covid - 19 terhadap Prekonomian Indonesia. Penelitian ini bertujuan untuk mengetahui dampak dari Covid-19 terhadap perekonomian Indonesia saat ini dan jenis penelitian ini merupakan jenis penelitian kepustakaan analisis data, reduksi data, display data dan verifikasi/kesimpulan hasil penelitian ini menunjukan dampak COVID-19 terhadap perekonomian Indonesia saat ini dengan berbagai dampak yang terjadi pada perekonomian karena pandemic Covid-19 yang terjadi pada sat ini maka itu perlu mengetahui dampak-dampak yang terjadi yaitu terjadi kesusahan dalam mencari lapangan pekerjaan,susah untuk memenuhi kebutuhan hidup sehari-hari dan juga tidak mempunyai penghasilan dalam memenuhi kebutuhan untuk sehari-hari dan juga banyak kesusahan yang di terima dari semua sektor perekonomian dalam semua bidang juga merasakan dampak dari Covid-19.

b. Sri Maryanti (2020). Pandemi COVID-19 dan implikasinya pada perekonomian Nusa Tenggara Barat. Hasil penelitian ini adalah saat ini Covid-19 bukan hanya menjadi ancaman bagi kesehatan manusia, tetapi juga sudah mulai mempengaruhi fundamental perekonomian NTB. Hal ini bisa dilihat dari terpukulnya beberapa sektor yang menjadi tumpuan ekonomi NTB seperti industri pariwisata, pertambangan dan sektor lainnya. Bahkan ekonom menyebutkan perekonomian NTB akan terkoreksi pada angka 3-4 persen. Terdapat 3 skenario perekonomian yang akan dihadapi NTB ditengah situasi Pandemi ini, yaitu tren pertumbuhan jangka panjang yang rendah, rebound pertumbuhan yang kuat, dan penurunan berkepanjangan tanpa pemulihan ekonomi. Pemprov NTB saat ini memiliki dua fokus utama untuk terhindar dari skenario ekonomi terburuk. Fokus dalam 
penanganan medis dan fokus menangani dampak negatif Covid-19 pada ekonomi. Beberapa langkah yang dilakukan adalah memangkas belanja yang bukan prioritas, realokasi anggaran, menjaga daya beli masyarakat dan mewujudkan stimulusstimulus ekonomi di daerah yang tepat sasaran.

c. Wuryandani (2020). Dampak pandemi COVID-19 Terhadap Pertumbuhan Ekonomi Indonesia 2020 dan Solusinya. Hasil Penelitian menunjukkan sejumlah negara di dunia telah mengalami resesi ekonomi akibat pandemi Covid-19. Hal tersebut terjadi setelah pertumbuhan ekonomi pada Kuartal I dan II 2020 menjadi minus. Beberapa negara yang mengalami resesi ekonomi antara lain Singapura, Korea Selatan, Jerman, Jepang, Perancis, Hong Kong, dan Amerika Serikat. Badan Pusat Statistik (BPS) mencatat penurunan pertumbuhan ekonomi Indonesia pada Triwulan II-2020 menjadi negatif $(-5,32 \%)$. Sebelumnya, pertumbuhan ekonomi Indonesia pada Triwulan I-2020 tercatat mencapai 2,97\% atau mulai menunjukkan adanya perlambatan. Tulisan ini bertujuan untuk mengkaji dampak Covid-19 terhadap perekonomian dan solusinya. Salah satunya adalah mempercepat belanja pemerintah atau menambah alokasi anggaran bantuan sosial dan bantuan langsung tunai. DPR dengan fungsi pengawasannya perlu mendesak pemerintah untuk membuat kebijakan yang sebaiknya diarahkan pada upaya mendorong percepatan pemulihan ekonomi nasional.

d. Darma (2020). Dampak pandemi COVID19 Terhadap Perekonomian Indonesia. Penelitian ini bertujuan untuk mengetahui dampak pandemi COVID-19 terhadap perekonomian Indonesia. Hingga penelitian ini ditulis ditemukan 93 negara yang telah terjangkit COVID-19. Pandemi COVID-19 yang telah menyebar pada akhirnya membawa risiko yang sangat buruk bagi perekonomian dunia termasuk
Indonesia khususnya dari sisi pariwisata, perdagangan serta investasi. Metode yang digunakan dalam penelitian ini adalah metode kuantitatif deskriptif dengan menggunakan pendekatan analisis data sekunder. Berdasarkan hasil penelitian, dampak pandemi COVID-19 menyebabkan rendahnya sentimen investor terhadap pasar yang pada akhirnya membawa pasar ke arah cenderung negatif. Langkah-langkah strategis terkait fiskal dan moneter sangat dibutuhkan untuk memberikan rangsangan ekonomi. Seiring berkembangnya kasus pandemi COVID-19, pasar lebih berfluktuasi ke arah yang negatif. Tidak hanya itu saja, lambatnya ekonomi global khususnya kegiatan ekspor Indonesia ke China juga berdampak signifikan terhadap perekonomian Indonesia. Hal tersebut berdasarkan analisis sensitivitas yang menjelaskan bahwa lambatnya ekonomi global saat ini sangat berdampak terhadap pertumbuhan perekonomian Indonesia.

e. Hadiwardoyo (2020). Kerugian Ekonomi Nasional Akibat Pandemi COVID-19. Hasil penelitian ini menunjukkan bahwa pembatasan aktivitas akibat pandemi Covid-19 telah menimbulkan kerugian ekonomi secara nasional. Kerugian itu hanya akan tertutupi apabila krisis dapat diakhiri sebelum menimbulkan kebangkrutan usaha secara massal. Tulisan ini dibuat sebelum PSBB (Pembatasan Sosial Berskala Besar) berakhir sehingga analisis ini masih didasarkan pada perhitungan apabila PSBB berjalan selama 1 bulan di area Jabodetabek. Sedangkan apabila PSBB diperlama dan atau diperluas ke kota-kota lain, maka otomatis dampak kerugian membesar, dan dapat diproyeksikan berdasar perbandingan waktu dan luasan area. Untuk memudahkan, pembahasan kerugian dibagi dalam kelompok kerugian nasional, sektoral, corporate, maupun individu. 


\section{DATA DAN METODOLOGI}

\section{Ruang Lingkup Penelitian}

Penelitian ini secara

khusus menganalisis perkembangan Makro ekonomi provinsi Aceh selama terjadi pandemi COVID-19 dari triwulan I dan triwulan II tahun 2020. Penelitian melihat setiap variabel yang ada dalam makro ekonomi dari sisi pengeluaran dan sisi lapangan usaha dan dianalisis satu persatu dengan membandingkan data pada triwulan I dengan data Triwulan II tahun 2020.

\section{Sumber dan Jenis Data}

Jenis data yang digunakan dalam penelitian ini meliputi data sekunder, data makro ekonomi yang sudah dioleh oleh lembaga pemerintah seperti BPS, Bank Indonesia dari triwulan I sampai triwulan II tahun 2020 .

\section{Model Analisis Data}

Metode penelitian yang digunakan dalam penelitian ini adalah dengan menggunakan metode penelitian yang bersifat kualitatif. Penelitian kualitatif adalah penelitian yang bersifat deskriptif dan cenderung menggunakan analisis. Data yang akan dianalisis dalam penelitian merupakan data ekonomi regional provinsi aceh yang di analisis dari beberapa variabel makro ekonomi.

\section{PEMBAHASAN}

\section{Perkembangan Ekonomi Makro Provinsi Aceh dilihat Dari Sisi Pengeluaran}

Grafik 4.1 Perkembangan sisi pengeluaran triwulan II

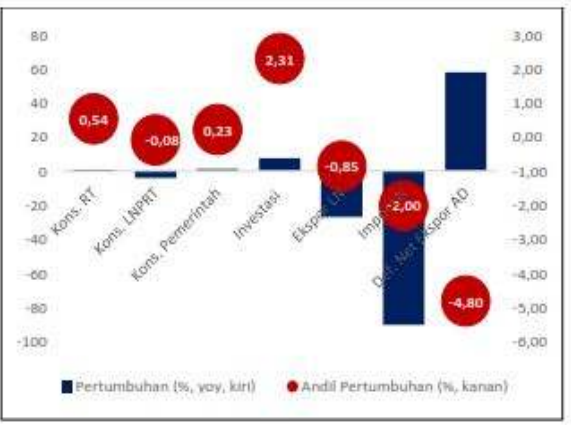

Sumber : BPS, BI, diolah
Jika dilihat dari sisi pengeluaran, kontraksi ekonomi aceh disebabkan meningkatnya defisit neraca ekspor antar daerah serta negatifnya kinerja ekspor luar negeri. Disisi lain, konsumsi rumah tangga sebagai komponen pengeluaran terbesar terbesar masih dapat tumbuh positif tapi melambat pada triwulan II. Komponen net ekspor antar daerah dan ekspor luar negeri memberikan tekanan tertinggi terhadap kontraksi makro ekonomi di aceh pada triwulan II.

\section{a. Konsumsi rumah tangga}

Pada triwulan II, konsumsi rumah tangga tumbuh sebesar $0,95 \%$ atau lebih lambat bila dibandingkan dengan pertumbuhan pada triwulan I sebesar 4,08\% dan memberikan andil sebesar 0,54\% terhadap kinerja perekonomian aceh. Perlambatan pertumbuhan konsumsi rumah tangga disebabkan oleh merebaknya COVID19 sehingga pemerintah dan pihak swasta mengeluarkan beberapa kebijakan diantaranya agar masyarakat tetap stay at home, penerapan physical distancing, penerapan jam malam di beberapa daerah, work from home (WFH) maupun pembatasan jam kerja pegawai sehingga akhirnya berdampak pada penurunan permintaan.

Selanjutnya, deselerasi konsumsi rumah tangga juga dipengaruhi oleh pendapatan masyarakat yang berkurang sebagai akibat dari kebijakan pihak swasta untuk merumahkan sementara atau melakukan Pemutusan Hubungan Kerja (PHK) kepada pegawainya di tengah aktivitas bisnis yang menurun pada era pandemi COVID-19. Data dari Kementerian Tenaga Kerja dan BPJS Tenaga Kerja menunjukkan bahwa sejak bulan awal tahun hingga bulan Juni 2020 terdapat 4.267 orang tenaga kerja di Aceh yang dirumahkan, sementara 3.942 orang lainnya mengalami Pemutusan Hubungan Kerja (PHK). 
Grafik. 4.2 indeks keyakinan konsumen

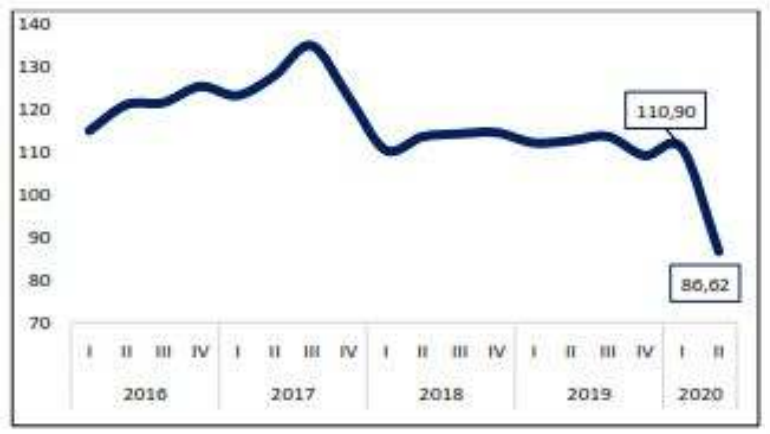

Sumber: Bank Indonesia, diolah

Melambatnya pertumbuhan konsumsi rumah tangga pada periode pelaporan tercermin dari beberapa indikator, yakni indek keyakinan konsumen (IKK) dan Kredit Konsumsi. Hasil survei konsumen yang dilakukan oleh Bank indonesia provinsi aceh yang memperlihatkan adanya penurunan IKK dari sebesar 110,90 poin pada triwulan I 2020 menjadi hanya sebesar 86,62 poin pada triwulan II. Di sisi lain kredit konsumsi juga mengindikasikan adanya perlambatan konsumsi rumah tangga karena deselerasii pertumbuhan ke level $3,85 \%$ dari sebelumnya $10,10 \%$.

\section{b. Konsumsi/pengeluaran Pemerintah}

Pada triwulan II, kinerja konsumsi pemerintah aceh mengalami pertumbuhan sebesar $1,26 \%$, lebih rendah dibandingkan periode sebelumnya yang terkontraksi sebesar 5,23\% Realisasi belanja seluruh pemerintah daerah di Provinsi Aceh (APBA + APBK) pada triwulan II 2020 tercatat sebesar 22,22\% atau setara dengan Rp10,90 triliun. Realisasi tersebut menurun bila dibandingkan dengan realisasi belanja pada periode yang sama di tahun 2019 yang berada di angka $25,54 \%$ atau setara dengan Rp12,20 triliun. Perlambatan realisasi belanja tersebut utamanya tidak terlepas dari terhambatnya proses administrasi pada periode COVID-19 serta adanya refocusing anggaran pemerintah untuk menanggulangi COVID-19.
Garfik 4.3 Pertumbuhan konsumsi pemerintah

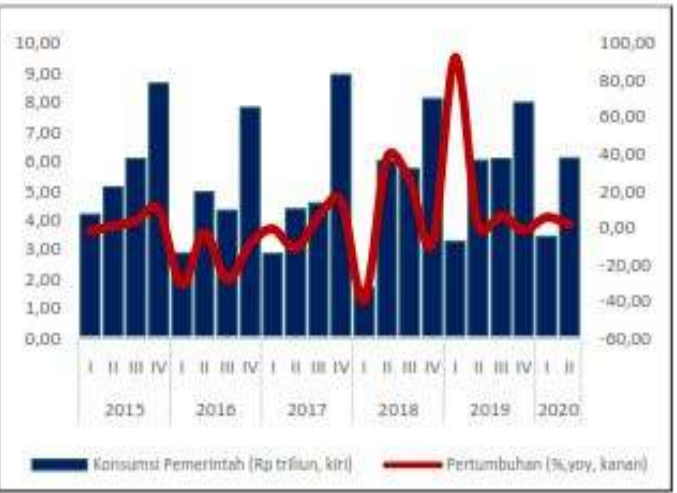

Sumber: BPS, diolah

Jika dilihat secara menyeluruh, penyebab lambatnya realisasi belanja pemerintah daerah disebabkan oleh penurunan realisasi pada tiga komponen belanja, yakni belanja pegawai, belanja bantuan keuangan, serta belanja bagi hasil. Komponen belanja pegawai hingga triwulan II tahun 2020 terealisasi sebesar 34,42\% dari total pagu anggaran belanja atau menurun dibandingkan dengan realisasi pada periode yang sama di tahun sebelumnya sebesar $38,25 \%$. Selanjutnya, realisasi belanja bantuan keuangan serta belanja bagi hasil masing-masing mencapai $13,23 \%$ dan $13,99 \%$, menurun dibandingkan dengan realisasi di tahun 2019 (21,33\% dan 61,32\%).

\section{c. Investasi/Pembentukan Modal Tetap Bruto}

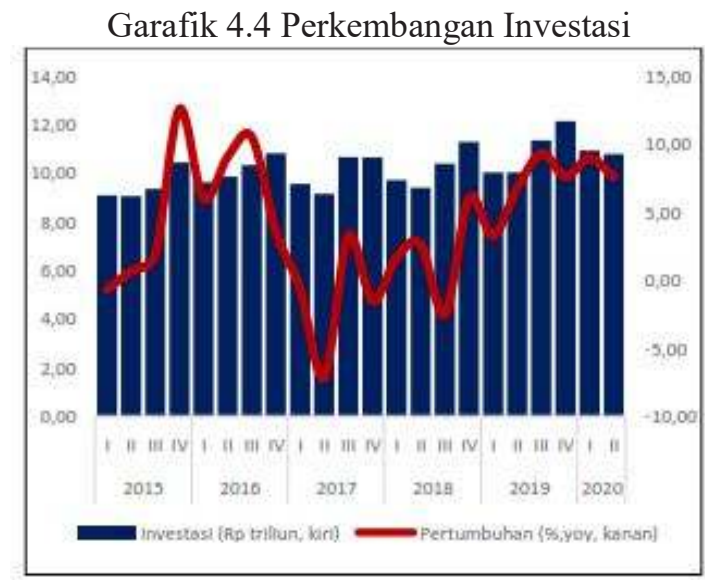

Sumber : BPS, diolah

Investasi di wilayah Aceh tumbuh di angka $7,57 \%$ pada triwulan II, lebih rendah 
dibandingkan capaian pada triwulan I 2020 yang tumbuh $8,95 \%$. Adanya deselerasi kinerja investasi tersebut seiring dengan melambatnya investasi swasta akibat cash flow perusahaan yang terganggu seiring dengan penurunan angka penjualan, sehingga perusahaan melakukan aksi wait and see. Selain itu, adanya kebijakan alokasi anggaran pemerintah untuk penanggulangan COVID19 juga turut menahan laju belanja modal pemerintah. Hingga triwulan II 2020, realisasi belanja modal seluruh pemerintah daerah di wilayah Aceh (Pemprov dan Pemkot/Pemkab) tercatat sebesar Rp 667,0 miliar, atau menurun dibandingkan dengan periode yang sama di tahun sebelumnya yang mencapai angka $\mathrm{Rp}$ 723,3 miliar.

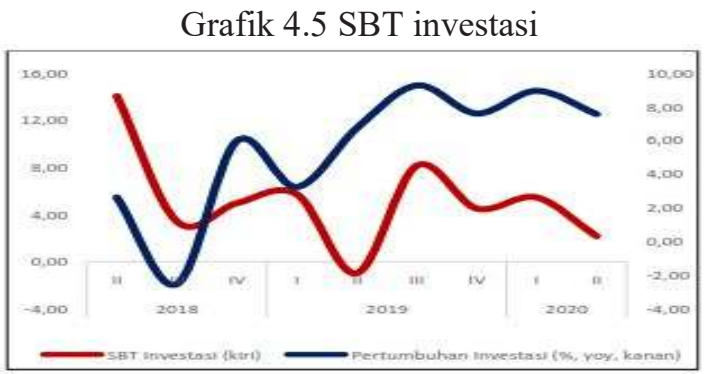

Sumber: Bank Indonesia, diolah

Deselerasi komponen investasi juga terkonfirmasi dari hasil Survei Kegiatan Dunia Usaha (SKDU) Bank Indonesia Provinsi Aceh yang memperlihatkan adanya Saldo Bersih Tertimbang (SBT) untuk variabel investasi di triwulan laporan menjadi 2,15, lebih rendah dibandingkan dengan triwulan sebelumnya yang berada di level 5,45. Dengan pertumbuhan tersebut, komponen $\mathrm{PMTB} /$ investasi tercatat memberikan kontribusi terhadap kinerja ekonomi Aceh secara keseluruhan pada periode laporan sebesar $2,84 \%$, atau menjadi sumber penahan utama agar kontraksi ekonomi tidak lebih dalam lagi.

\section{d. Ekspor Luar Negeri}

Ekspor luar negeri Provinsi Aceh pada triwulan II 2020 tercatat terkontraksi $26,97 \%$, turun dalam dibandingkan dengan pertumbuhan triwulan sebelumnya yang berada di angka 45,92\% . Total barang dari
Aceh yang di ekspor ke luar negeri pada triwulan II 2020 tercatat hanya sebesar USD 58,24 juta, atau menurun signifikan bila dibandingkan dengan periode sebelumnya di level USD 94,63 juta. Secara kelompok barang, penurunan tersebut utamanya disebabkan oleh menurunnya nilai ekspor kelompok bahan bakar mineral (komoditas batu bara) dari sebesar USD 51,04 juta menjadi sebesar USD 25,45 juta. Penurunan ekspor batu bara ini utamanya disebabkan oleh turunnya permintaan dari negara importir utama batu bara yakni India sebagai dampak dari kebijakan lockdown negara tersebut di tengah pandemi COVID-19 yang menghambat proses distribusi serta adanya kebijakan Menteri Energi dan Mineral India untuk mulai mengutamakan penggunaan batu bara hasil produksi dalam negeri dibandingkan dengan batu bara impor.

Grafik 4.6 Pertumbuhan ekspor luar negeri

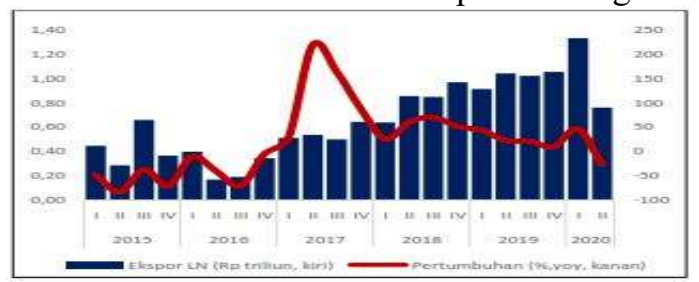

Sumber : BPS, diolah

Kinerja ekspor kelompok kopi, teh dan rempah-rempah (mayoritas kopi) sebagai penyumbang terbesar kedua bagi ekspor luar negeri Aceh pada triwulan laporan juga tercatat mengalami penurunan dari USD 26,02 juta menjadi hanya sebesar USD 18,38 juta. Hal tersebut didorong oleh menurunnya permintaan dari negara importir utama seperti Amerika Serikat di tengah banyaknya café/restoran yang menutup sementara operasionalnya di tengah penyebaran COVID-19. Dengan kontraksi sebesar $26,97 \%$ pada triwulan laporan, maka ekspor luar negeri Aceh memberikan kontribusi negatif sebesar $0,85 \%$ terhadap kinerja ekonomi Aceh secara keseluruhan pada triwulan II 2020. 


\section{e. Import Luar Negeri}

Komponen impor luar negeri pada triwulan II 2020 tercatat terkontraksi sebesar $-90,23 \%$, turun dalam dibandingkan triwulan sebelumnya yang tumbuh $0,94 \%$. Total barang yang diimpor Aceh dari luar negeri pada triwulan II 2020 tercatat sebesar USD 2,60 juta, atau menurun cukup signifikan dibandingkan dengan periode sebelumnya di level USD 4,50 juta. Secara kelompok barang, penurunan tersebut utamanya disebabkan oleh tidak adanya impor kelompok benda bahan kimia organik pada triwulan laporan, turun signifikan dari sebesar USD 0,66 juta pada periode sebelumnya.

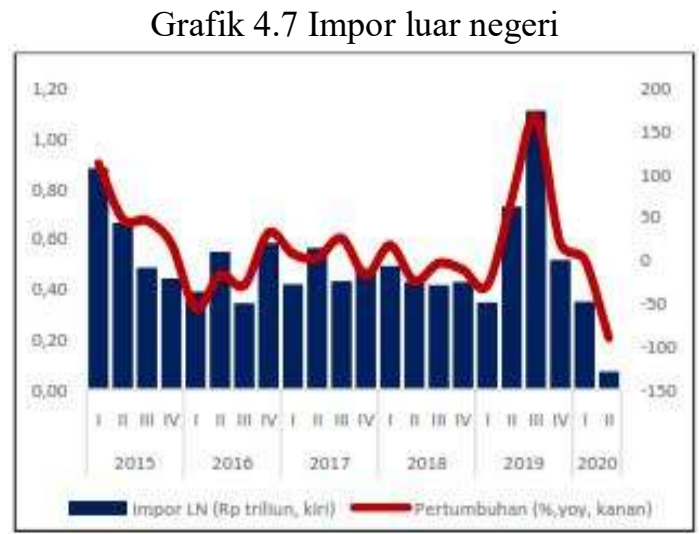

Sumber: BPS, diolah

Kinerja impor barang pada kelompok garam, belerang, dan kapur sebagai salah satu penyumbang terbesar bagi impor luar negeri Aceh pada triwulan laporan juga tercatat mengalami penurunan dari USD 489,7 ribu menjadi USD 244,4 ribu. Secara umum untuk jangka pendek, perlambatan nilai impor tersebut membuat kontraksi ekonomi Aceh pada triwulan laporan tidak menjadi lebih dalam. Dengan kontraksi sebesar -90,23\% pada triwulan laporan, maka impor luar negeri Aceh memberikan kontribusi positif sebesar 2,00\% terhadap kinerja ekonomi Aceh secara keseluruhan.

\section{f. Net Ekspor Antar Daerah}

Grafik 4.8 Pertumbuhan defisit net ekspor antar daerah

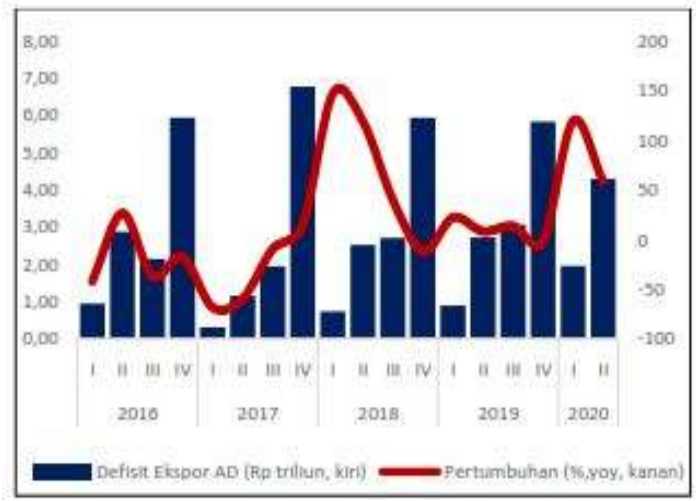

Sumber : BPS, diolah

Provinsi Aceh mencatatkan defisit net ekspor antar daerah yang semakin besar. Pada triwulan II 2020, defisit ekspor antar daerah tercatat meningkat sebesar 58,03\%. Namun demikian, peningkatan tersebut masih lebih rendah dibandingkan dengan periode sebelumnya yang mencapai $119,16 \%$. Pada triwulan II 2020, defisit net ekspor antar daerah Aceh tercatat sebesar Rp4,29 triliun (ADHK), meningkat dibandingkan dengan periode sebelumnya di angka Rp1,95 triliun. Peningkatan defisit tersebut seiring dengan ekspor antar daerah Aceh yang menurun, tercermin dari data muat barang pelabuhan utama di Aceh yang sebelumnya di angka 306,3 ribu ton menjadi hanya 172,4 ribu ton pada periode laporan. Dengan pertumbuhan sebesar 58,03\% pada triwulan laporan, maka net ekspor antar daerah Aceh memberikan kontribusi negatif sebesar $-4,80 \%$ terhadap kinerja ekonomi Aceh secara keseluruhan pada triwulan II 2020. Hal tersebut membuat net ekspor antar daerah menjadi komponen utama penyebab kontraksi ekonomi pada periode laporan dari sisi pengeluaran. 


\section{Perkembangan Ekonomi Makro Provinsi Aceh dilihat Dari Sisi Lapangan Usaha}

Grafik 4.9 Perkembangan dari Sisi Lapangan Usaha

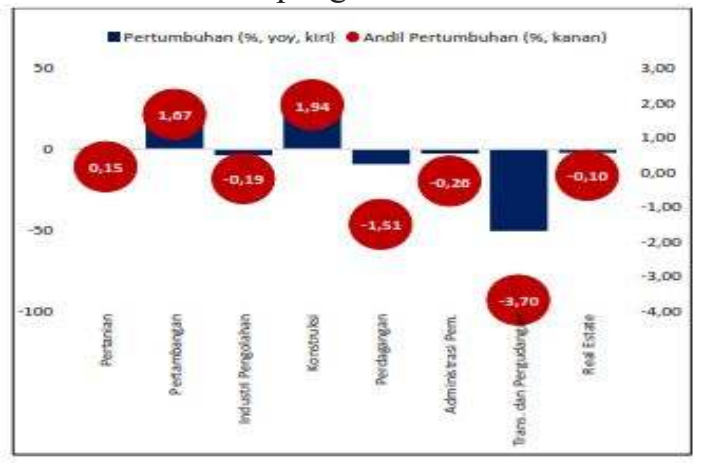

Dilihat dari sisi lapangan usaha, kontraksi ekonomi Aceh utamanya disebabkan oleh penurunan kinerja beberapa lapangan usaha utama, seperti transportasi dan pergudangan serta perdagangan besar dan eceran. Di sisi lain, akselerasi kinerja lapangan usaha konstruksi serta pertambangan dan penggalian menahan kontraksi lebih dalam lagi. Secara andil, lapangan usaha transportasi dan pergudangan serta perdagangan besar dan eceran adalah lapangan usaha yang memberikan andil kontraksi terdalam terhadap kinerja ekonomi pada triwulan laporan. Masing-masing lapangan usaha memberikan andil sebesar $3,70 \%$ dan $-1,52 \%$. Tingginya andil kontraksi lapangan usaha transportasi dan pergudangan sejalan dengan turunnya kinerja yang sangat dalam pada periode laporan. Lebih lanjut tingginya andil dari lapangan usaha perdagangan besar dan eceran sejalan dengan besarnya distribusi lapangan usaha tersebut yakni 15,16\% dari total perekonomian Aceh. Di sisi lain, lapangan usaha pertanian masih menjadi penyokong terbesar perekonomian dengan andil sebesar 30,92\%.

\section{a. Lapangan Usaha Pertanian, Perikanan, dan Kehutanan}

Kinerja lapangan usaha pertanian pada triwulan II 2020 tercatat tumbuh di angka $0,54 \%$ dan memberikan andil $0,15 \%$ terhadap kinerja ekonomi Aceh secara keseluruhan atau lebih rendah dibandingkan dengan triwulan sebelumnya yang berada di level $6,06 \%$. Deselerasi pertumbuhan tersebut utamanya sebagai dampak dari berakhirnya musim panen tanaman bahan makanan (padi dan jagung) di beberapa wilayah sentra serta berkurangnya produksi beberapa komoditas hortikultura seperti bawang merah dan tomat. Selanjutnya, menurunnya harga Crude Palm Oil (CPO) yang diikuti penurunan harga Tandan Buah Segar (TBS) sawit juga turut memperlambat pertumbuhan lapangan usaha pertanian pada periode laporan. Pada triwulan II 2020, produksi padi di Aceh tercatat sebesar 346,1 ribu ton, menurun dibandingkan dengan produksi di periode sebelumnya di angka 657,4 ribu ton. Selanjutnya, produksi komoditas bawang merah dan tomat pun berkurang pada periode laporan masing-masing menjadi hanya sebesar 9,3 ribu ton dan 61,3 ribu ton dari sebelumnya di angka 12,6 ribu ton dan 96,5 ribu ton. Lebih lanjut, perlambatan pertumbuhan lapangan usaha pertanian pada triwulan laporan juga disebabkan oleh menurunnya rata-rata harga CPO dari sebelumnya USD 640,19/MT menjadi hanya sebesar USD 528,09/MT.

Grafik 4.10 Pertumbuhan Lapangan Usaha Pertanian

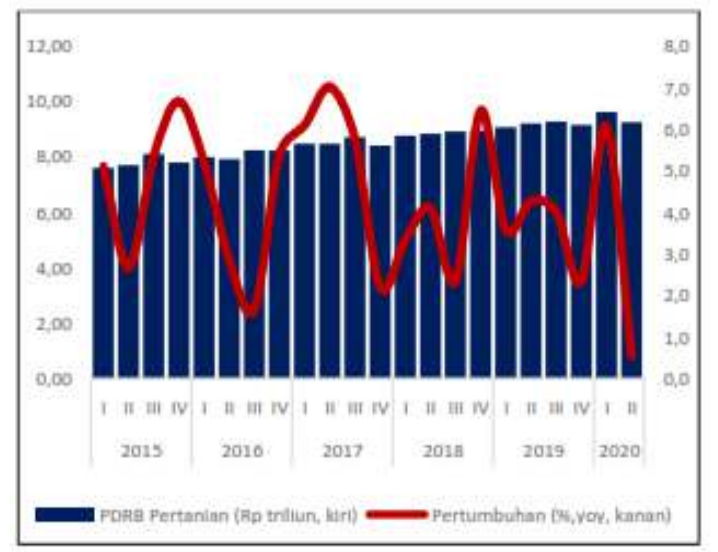

Sumber : BPS, diolah

Kondisi kinerja lapangan usaha pertanian pada triwulan laporan yang mengalami deselerasi dibandingkan dengan triwulan sebelumnya terkonfirmasi dari hasil Survei Kegiatan Dunia Usaha (SKDU) Bank 
Indonesia Aceh. SKDU tersebut menunjukan adanya penurunan Saldo Bersih Tertimbang (SBT) penggunaan tenaga kerja untuk lapangan usaha pertanian yang pada triwulan I 2020 di angka 0,39 menjadi sebesar -2,09 di triwulan laporan. Hal tersebut menunjukkan adanya penurunan jumlah tenaga kerja yang bekerja di lapangan usaha pertanian pada periode laporan.

\section{b. Lapangan Usaha Perdagangan}

Grafik 4.11 Perkembangan Lapangan Usaha Perdagangan

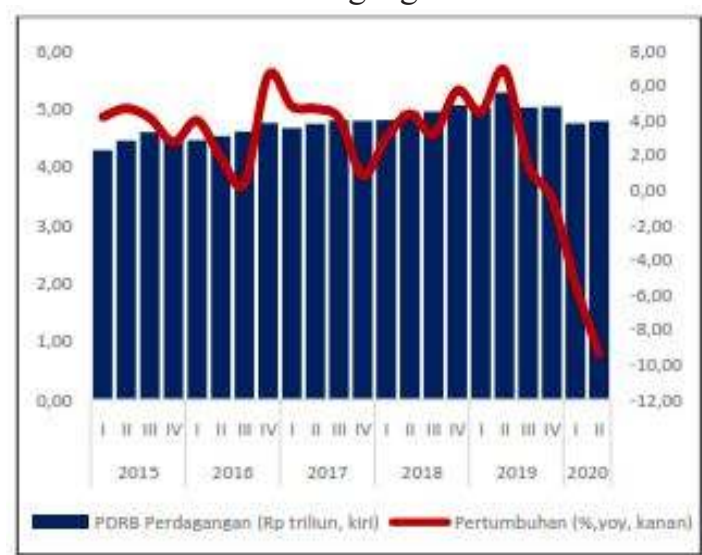

Sumber: BPS diolah

Lapangan usaha perdagangan pada triwulan laporan tercatat terkontraksi $-9,38 \%$, lebih dalam dibandingkan dengan triwulan sebelumnya yang terkontraksi $-5,41 \%$ dan memberikan andil $-1,51 \%$ terhadap kinerja ekonomi periode laporan. Kontraksi tersebut terjadi utamanya sebagai dampak dari berkurangnya aktivitas masyarakat di tengah merebaknya COVID-19 sehingga pemerintah dan pihak swasta mengeluarkan beberapa kebijakan diantaranya agar masyarakat tetap stay at home, penerapan physical distancing, penerapan jam malam di beberapa daerah, Work From Home (WFH), pembatasan jam kerja pegawai maupun penundaan/ pembatalan kegiatan MICE (Meeting, Incentives, Conferences, and Exhibition) sehingga pada akhirnya berdampak pada penurunan aktivitas perdagangan. Selanjutnya, aktivitas perdagangan juga menurun dipengaruhi oleh pendapatan masyarakat yang berkurang sebagai akibat dari kebijakan pihak swasta untuk 188 merumahkan sementara atau melakukan Pemutusan Hubungan Kerja (PHK) kepada pegawainya di tengah aktivitas bisnis yang menurun pada era pandemi COVID-19.

Kontraksi pada lapangan usaha perdagangan tersebut terkonfirmasi salah satunya dari angka penjualan kendaraan bermotor. Pada triwulan II 2020, penjualan kendaraan bermotor di Provinsi Aceh tercatat hanya sebesar 24,7 ribu unit, lebih rendah dibandingkan dengan penjualan kendaraan di periode sebelumnya yang mencapai 28,2 ribu unit dan periode yang sama di tahun sebelumnya di angka 29,5 ribu unit. Lebih lanjut, kontraksi kinerja lapangan usaha perdagangan pun terkonfirmasi dari hasil Survei Konsumen Bank Indonesia Provinsi Aceh yang menunjukkan adanya penurunan pada rata-rata indeks konsumsi masyarakat untuk barang-barang tahan lama dari sebelumnya di angka 124,38 menjadi hanya sebesar 107,81 pada periode laporan.

\section{c. Lapangan Usaha Konstruksi}

Grafik 4.12 Perkembangan Lapangan Usaha Konstruksi

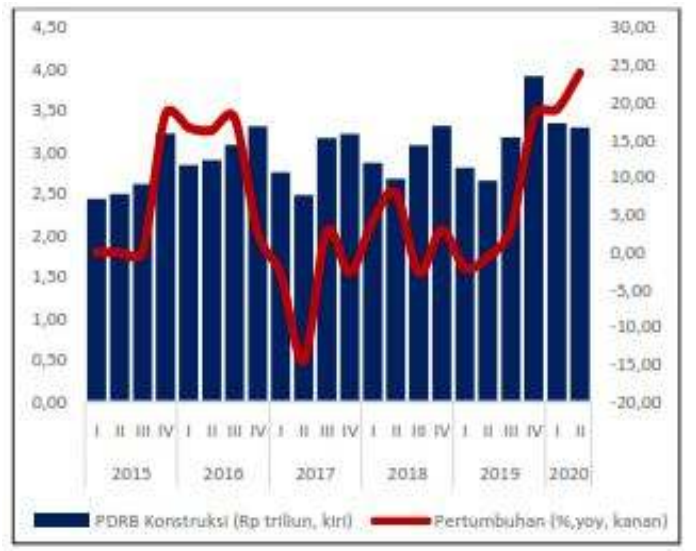

Sumber: BPS, diolah

Secara umum pada triwulan II 2020, kinerja lapangan usaha konstruksi mengalami akselerasi dibanding periode sebelumnya. Pada triwulan laporan, lapangan usaha konstruksi tumbuh sebesar 23,94\%, meningkat dibandingkan dengan triwulan sebelumnya yang tumbuh $19,06 \%$. Capaian pertumbuhan tersebut juga tercatat lebih tinggi dibandingkan dengan periode yang sama di tahun sebelumnya (kontraksi 0,69\%. 
Dengan pertumbuhan tersebut, lapangan usaha konstruksi tercatat menjadi LU utama yang menahan kontraksi dengan memberikan andil positif terhadap kinerja ekonomi Aceh pada periode laporan sebesar $1,94 \%$. Adanya peningkatan kinerja lapangan usaha konstruksi seiring dengan kelanjutan pembangunan Program Strategis Nasional (PSN) pada triwulan laporan, yaitu pembangunan jalan tol sepanjang Banda Aceh hingga Sigli yang termasuk kedalam PSN Jalan Tol Trans Sumatera (JTTS). Lebih lanjut, pembangunan Waduk Keureuto serta PLTA Peusangan yang masih berjalan hingga triwulan laporan juga mendongkrak kinerja lapangan usaha konstruksi. Selain proyek dari pemerintah daerah atau pemerintah pusat, investasi bangunan dari pihak swasta pun meningkat pada triwulan laporan. Investasi fisik pihak swasta pada triwulan laporan diantaranya adalah pembangunan pabrik pupuk di wilayah Lhokseumawe, pembangunan hotel di Banda Aceh dan wilayah Tengah Aceh, serta pembangunan pusat perbelanjaan di Banda Aceh. Akselerasi yang terjadi pada lapangan usaha konstruksi di triwulan II 2020 tercermin salah satunya dari pertumbuhan realisasi pengadaan komoditas semen. Pengadaan komoditas dimaksud di Aceh menunjukkan akselerasi dengan tumbuh sebesar 44,74\%, lebih tinggi dibandingkan dengan triwulan sebelumnya di angka 19,98\%. Pertumbuhan tersebut bahkan tercatat jauh lebih tinggi dibanding kinerja pada periode yang sama di tahun sebelumnya yang terkontraksi $6,68 \%$.

\section{d. Lapangan Usaha Pertambangan}

Pada triwulan laporan, kinerja lapangan usaha pertambangan dan penggalian tercatat tumbuh $23,32 \%$, meningkat cukup signifikan dibandingkan dengan triwulan sebelumnya yang terkontraksi di angka $-5,83 \%$. Meningkatnya kinerja lapangan usaha pertambangan dan penggalian utamanya seiring dengan menguatnya sub lapangan usaha pertambangan minyak dan gas bumi. Hal tersebut seiring dengan kembali normalnya aktivitas salah satu kilang gas di pesisir timur Aceh pada periode laporan setelah pada periode sebelumnya aktivitas sempat terhenti dikarenakan adanya proses konstruksi penguatan tanah selama kurang lebih tiga bulan. Dengan pertumbuhan tersebut, lapangan usaha pertambangan dan penggalian tercatat memberikan kontribusi positif terhadap kinerja ekonomi Aceh pada periode laporan sebesar 1,67\%.

Grafik 4.13 Perkembangan Lapangan Usaha Pertambangan

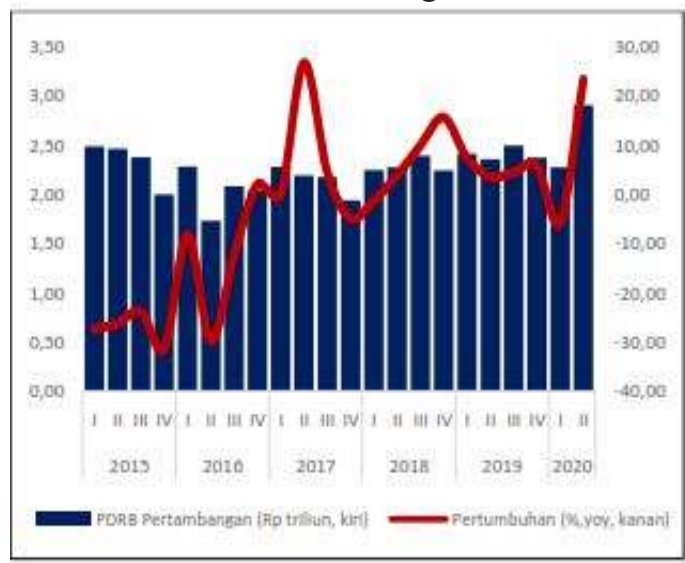

Sumber : BPS, diolah

Kinerja lapangan usaha pertambangan dan penggalian pada triwulan III 2020 diperkirakan akan semakin meningkat. Hal tersebut utamanya didukung oleh permintaan komoditas batubara global yang mulai meningkat sejalan dengan perbaikan ekonomi Tiongkok pasca berakhirnya periode lockdown. Selanjutnya, meningkatnya permintaan dari Tiongkok tersebut diperkirakan akan mampu mendorong harga batu bara untuk terakselerasi dikarenakan Tiongkok adalah konsumen terbesar komoditas batu bara di dunia.

\section{E. KESIMPULAN}

Berdasarkan hasil penelitian yang telah dilakukan maka dapat diambil kesimpulan sebagai berikut: jika dilihat dari sisi pengeluaran, penyebab utama terjadinya kontraksi ekonomi makro di provinsi aceh adalah menurunnya net ekspor antar daerah serta melambatnya konsumsi rumah tangga atau menurunnya daya beli masyarakat yang 
disebabkan adanya pembatasan sosial yang membatasi aktivitas masyarakat dalam berusaha. Dilihat dari lapangan usaha, kontraksi ekonomi makro provinsi aceh utamanya disebabkan oleh penurunan kinerja pada lapangan usaha transportasi, pergudangan dan perdagangan. Terjadinya pembatasan sosial menyebabkan bidang transportasi mengalami penurunan aktivitas yang menyebabkan akses pengiriman barang dan jasa terganggu, tidak lancarnya arus barang dan jasa mengakibatkan kegiatan perdagangan di provinsi juga mengalami penurunan kegiatan, di tambah lagi terbatasnya daya beli masyarakat, dan terjanya PHK dimasa pandemi COVID-19.

\section{DAFTAR PUSTAKA}

Darma, D. A (2020). Dampak Pandemi COVID-19 Terhadap Perekonomian Indonesia. Jurnal Benefita 5(2) Juli $2020(212-224)$

Hadiwardoyo, W. (2020). Kerugian Ekonomi Nasional Akibat Pandemi COVID-19. Journal of Business and Entrepreneurship Volume 2 No. 2 April 2020 jurnal.umj.ac.id.
Hanoatubun, S. (2020). Dampak Covid - 19 terhadap Perekonomian Indonesia. EduPsyCouns: Journal of Education, Psychology and Counseling, 2(1),

Mankiw, N, Gregory, Macroeconomic, 2010, 7th edition, worth Publisher

Maryanti, S. (2020). Pandemi COVID-19 dan implikasinya pada perekonomian NTB. ejurnal.binawakya.or.id Vol. 14 No. 11.

Sadono Sukirno, Pengantar Teori Ekonomi Makro, (Jakarta: Predana Media Group, 2012)

Todaro, Smith. Economic Development, Pearson Education Limited, United Kingdom (2013)

Wuryandani, D. (2020). Dampak Pandemi COVID-19 Terhadap Pertumbuhan Ekonomi Indonesia. Kajian Singkat Terhadap Isu Aktuan dan Strategis Bidang Ekonomi dan Kebijakan Publik. Vol. XII, No. 15/I/Puslit

www.BI.go.id

www.BPS.go.id

www.Indonesia.covid19.go.id (per 19 Okt 2020). 